\title{
A Probable Etiology and Pathomechanism of Arousal and Anxiety on Cellular Level - Is It the Key for Recovering from Exaggerated Anxiety?
}

\author{
András Sikter ${ }^{1}$ and Roberto De Guevara ${ }^{2}$ \\ ${ }^{1}$ Municipal Clinic of Szentendre, Internal Medicine \\ ${ }^{2}$ Breathing trainer, Colorado Springs \\ ${ }^{1}$ Hungary \\ 2United States of America
}

\section{Introduction}

How can stress of life evoke anxiety through the rather simple second messenger system? What is the main difference between acute stress response of humans and wild animals? What are the role of catecholamines and the alterations of carbon dioxide levels in anxiety disorder? How is it possible, that the same kind of stress causes very different symptoms and disorders in different people? How does the Path of Least Resistance work, and what is its importance? Do diseases of any etiology have a common pathogenetic root as a manifestation of the Second Law of Thermodynamics? What is the difference between functional and organic brain disorders at the cellular level? What is the pathomechanism of arousal and anxiety on cellular level? How does personality and behaviour affect one`s exposure to diseases? These are not easy questions, and we don't expect to find perfectly accurate answers to all of them. Especially not as we consider, that several decades were not enough to resolve the debate whether hypocapnia would cause anxiety, anxiety would evoke hypocapnia, or they would be mutually correlated making both statements true (Meuret et al., 2005). Although there is a huge amount of controversial data available that cause uncertainty, the authors try to answer these questions.

The BASIC idea of Sick Cell Syndrome is connected to Elkinton (1956). A modified universal disease model of Sick Cell Syndrome was constructed by author Sikter (published in 2007, Hungarian). The model is based on the Second Law of Thermodynamics. It is theoretical and practical as well. Adapting it properly may be a key for treating anxiety disorder up to "restitutio ad integrum". Since Kerr et al`s 1937 publication (as cited in Lum, 1981) there has been a long lasting dispute those who believe anxiety is caused by the lack of carbon dioxide, and those who insist that anxiety induces hypocapnia. Lum wrote the following in an editorial: "Although Kerr et al. (1937) had pointed out that the clinical manifestations of anxiety state were produced by hyperventilation, it was Rice (1950) who turned this concept upside down by stating that the anxiety was produced by the symptoms and, furthermore, that patients could be cured by eliminating faulty breathing habits. Lewis (1964) identified the role of anxiety as a trigger, rather than the prime cause. Given habitual hyperventilation, a variety of triggers, psychic or somatic, can initiate the vicious cycle of increased breathing, 
symptoms, anxiety arising from symptoms exacerbating hyperventilation and thus generating more symptoms and more anxiety." Shortly after the conceptualization of panic disorder in the DSM III (1980), it became evident that there is an overlap between symptoms of the hyperventilation syndrome and panic disorder (Cowly \& Roy-Byrne, 1987). Though psychiatrists see essential differences between the hyperventilation syndrome and anxiety disorder, practitioners of related fields do not (Han et al., 1997). "The patients in the present study (hyperventilators and patients with anxiety disorders) were diagnosed on different bases. However, the breathing pattern of patients with anxiety and hyperventilation syndrome is similar." The authors of this chapter argue that the truth is somewhere in the middle; that none of the original statements are false, and that the nature of the syndrome is best described by the vicious cycle concept of Lewis (1964 as cited in Lum, 1981). Hypocapnia can elicit somatic sensations, and the fear from these bodily sensations is capable to generate anxiety. On the other hand, anxiety is able to provoke hypocapnia, thus providing conditions for a vicious cycle.

\section{Supposed mechanism of arousal. Is arousal linked to intracellular $\mathrm{pH}$ ?}

The roles of $\mathrm{Ca}^{2+}$ current (as second messenger) in the release of neurotransmitters and in the action potential of neurons (Neher, 1998) are well known, but less is the fact, that the low cytosolic $\mathrm{H}^{+}$concentration (cytosolic alkalosis) influences $\mathrm{Ca}^{2+}$ conductance as second/third messenger (Tombaugh \& Somjen, 1997). Intracellular $\mathrm{pH}$ is strictly regulated (Boron, 2004) in the brain cells as well, and even marginal change of $\mathrm{H}^{+}$concentration may cause big functional alterations in neurons. Carbon dioxide concentration is one of the most important factors that influence the intra- and extracellular $\mathrm{pH} . \mathrm{CO}_{2}$ is extremely diffusible and when the breathing pattern changes--i.e. breathing slows down or accelerates--it will results in rapid changes of $\mathrm{H}^{+}$concentration both the intracellular and extracellular compartment, practically in all tissues and practically at the same time. $\mathrm{CO}_{2}$ passes through the cellmembranes very quickly, and it forms carbonic acid with $\mathrm{H}_{2} \mathrm{O}$ molecules which results in more $\mathrm{H}^{+}$ions in the cytosol. On the other hand, ions, including the $\mathrm{H}^{+}$ion, move slowly through membranes; this is explained by the fact that when electrically charged ions become hydrated, their radius gets multiplied. Conversely, $\mathrm{CO}_{2}$ doesn't have either of these attributes and it is also soluble in lipids. Breathing deeply or frequently, the pulse speeds up, suggesting that $\mathrm{CO}_{2}$ has left the pacemaker cells of the heart, and the alkalic cytoplasm allows $\mathrm{Ca}^{2+}$ to enter into the cytosol. Breathing this way for a longer time, the pulse will slowly come back to the initial rate, because the organism compensates the alteration of $\mathrm{pH}$ in the cytosol. The paucity of $\mathrm{H}^{+}$in the cytosol increases conductance of $\mathrm{Ca}^{2+}$ and some other ions (Harvey et al., 1988), thus it increases contraction, metabolism and $\mathrm{O}_{2}$ requirement of the tissues (Laffey et al., 2002), and also increases excitability both in peripheral and central neurons (Stenkamp et al., 2001). All these events can be explained by the simple fact, that the alkalosis increases transmembrane conductance of ions and consequently increases active ion-pumping mechanisms as well, (thus restoring the original ion status.). By contrast, acidosis decreases $\mathrm{Ca}^{2+}$ conductance (Tombaugh \& Somjen, 1997), and it also decreases excitability of the neurons, and the decreased $\mathrm{Ca}^{2+}$ conductance can dramatically affect the neurotransmitter release (Dodge \& Rahamimoff, 1967). In some cells the $\mathrm{Ca}^{2+}$ entry into the cytosol itself increases cytosolic $\mathrm{H}+$ concentration, which physiological acidosis then limits the further $\mathrm{Ca}^{2+}$ entry. It is supposed to be a novel feedback mechanism (Tombaugh, 1998). Carbon dioxide is an important link between psyche and corpus. Our emotions, actual 
spiritual status and personality influence our breathing patterns (i.e. breathing rarely, frequently, irregularly) causing $\mathrm{pH}$ alteration in the organism. In this manner, the actual cytosolic $\mathrm{pH}$ of neurons affects arousal by modifying $\mathrm{Ca}^{2+}$ conductance, establishing a particular feedback mechanism. The concentration of carbon dioxide can alter the whole organism at the same time because of its extremely high penetrance. If the the concentration thus altered endures for a long time (several hours to a week), the organism starts to "compensate". Stability of extra- and intracellular $\mathrm{pH}$ is of high priority. Renal function and various tissue buffer mechanisms (mostly) restore the $\mathrm{pH}$ in the intra- and extracellular space, but the concentration of other ions in the cytosol remains altered for longer. The development of the new ionmilieu needs 5-7 days (Gennari et al., 1972). The new ionmilieu of the cells differs from the physiological one (restoration of the original ionmilieu would take another 5-7 days at least). Then chronic hypocapnia or hypercapnia is followed by cascades that alter the whole ionmileu in the cells. They may even alter the neurotransmitter/endocrine status (Dodge et al., 1967; Bailey et al., 2003).

Human is a species especially vulnerable to the long-term alteration of carbon dioxide levels. The explanation of this is the fact that humans become hypo- or hypercapnic not only by organic diseases, but by mental disorders as well, and - most importantly -- because of learned behaviours. This latter can be dangerous, because it may result in diseases of civilization (Sikter et al., 2009). It is frequently asserted that it is the "stress of life" itself that causes diseases of civilization (induced by "stress-hormones") (Selye, 1956). This statement might be incorrect in that wild animals don't get diseases of civilization, (except if they are living near civilization) even though they are at least as much stressed as human beings are. Wild animals behave and react according to their instincts. According to our viewpoint, in this acute stress response the most important factors to consider are the strong catecholamine (e.g. noradrenaline) rush and acute hypocapnia. During this hyperarousal condition wild animals will fight or flee. This exertion results in increased carbon dioxide production and this in turn restores the biochemistry and physiology. Human hyperarousal stress response is biphasic, but it is also accompanied by hypocapnia. (See below.) In their response to stress human beings differ from wild animals in that their response to stress is more complex. They can mostly restrain their temper, thus often physical activity will not follow hyperarousal stress. Moreover, the enduring hypocapnia would result in ionmovements through membranes, causing metabolic, endocrine alterations, and illnesses because of the alteration of "milieu interieur". Namely, diseases of civilization are caused by the distress evoked by the lack of instinctive reaction to stress. Animals become anxious and depressed after chronic immobilization (Joo et al., 2009), while humans are usually immobilized by their "civilized behaviour", and social norms.

Cannon's (1929) work on "fight or flight" stress response continues to be valid. (Stress evokes catecholamine rush and hypocapnia at the same time, which together result in a very strong sympathetic answer, hyperarousal.) There are several differences in the case of primates (Bracha, 2004). Homo sapiens begins with an „initial freeze response”. According to Bracha, it is because mammalian carnivores are capable to see moving objects only. This is a hypoventilation/hypoarousal state with decelerated pulse. The fear-stressed human "stops, looks, and listens." This initial answer can be followed by two alternative ways. It can be followed by a hypocapnic response (this way of the reaction becomes very similar to the known Cannonian "fight or flight" stress response). Second possibility is the "tonic immobility" (Bracha, 2004), or "defensive immobility" (Van Diest et al., 2009). This is a 
confirmation of the initial freeze response to a deeper hypoarousal state. (It was reffered to as "freezing behaviour and playing dead" in the early literature.) This is an explicit hypocapnic state with decelerated pulse and immobility. The animal/human is vigilant but is not capable (has no energy) to "fight or flight", although it can switch to hyperventilate and become hyperaroused if it seems to be practical. The hypoarousal fear responses and the relating hypercapnic breathing patterns are poorly studied (Van Diest et al., 2009).

It is not a widely known fact that there is a feedback mechanism between the catecholamine levels of tissues and intracellular $\mathrm{pH}$ (Tenney, 1960). In acidic conditions responsiveness to catecholamines dramatically decreases while catecholamine output increases. In spite of these compensatory processes the sympathicotonia and arousal decrease (Kuijpers et al., 1989). By contrast, responsiveness to catecholemines, sympathicotonia and arousal increase in alkalosis, (even though catecholamine output slightly decreases). Catecholamines increase $\mathrm{Na}^{+} / \mathrm{H}^{+}$exchange in the cells that causes alkalosis in cytosol, similarly to the effect of hypocapnia. It might not be a coincidence. The Cannonian "fight or flight" response is a strong hyperarousal reaction because both catecholaminemia and hypocapnia cause alkalosis in the cytosol. In the case of humans the initial hypercapnia generates heavy catecholamine output. Then the cells become alkalotic via hypocapnia and hypersensitive to catecholamines. This biphasic hyperarousal stress response is characteristic not only of primates but of several other animals (e.g. opossum, some fish species, amphibians, reptiles, birds). Also well established is the fact that in the case of the ptarmigan hen the two phases of stress response were very pronounced and well distinguishable (Steen et al., 1988). In the first phase of stress, the hen's respiratory and pulse rate would decelerate. After several minutes the hen would suddenly start to hyperventilate, and the hypoarousal condition would convert to a very vigorous hyperarousal with up to two to three times faster pulse. In this, the hypercapnic period of breathing was followed by a hypocapnic one, similarly to symptoms of human panic disorder. (See below.)

\section{Anxiety. The importance of breathing irregularity}

Both hyperarousal and anxiety may elicit a physiological "fight or flight" response, but there are essential differences between them. Arousal is physiological, while anxiety is rather a psychological phenomenon. Anxiety develops via psychogenic pathomechanism, while the high arousal is one of the most important triggers of anxiety. Anxiety can occur without exposure to an external stressor and it is usually longer lived than arousal. High arousal is a precondition of anxiety, although anxiety is also a result of learning/conditioning process. High arousal can lead to anxiety while low arousal level can result in depression. Modern neuroimaging techniques have made anxiety-research an objective science (Sehlmeyer et al., 2009). The authors of this chapter emphasize the importance of altering carbon dioxide level both in hyperarousal and anxiety. According to author Sikter, the irregular breathing patterns in the pathomechanism of anxiety are as important as hypocapnia itself. The breathing irregularity is especially high in panic disorder but is also present in GAD patient (Wilhelm, 2001b). "The control of breathing is a complex interplay that relies on many factors, including the bulbopontine respiratory network, central and peripheral chemoreceptor control, modulation of respiratory muscles by mechanoreceptors, and numerous suprapontine networks located in the limbic, cerebellar, and cortical areas" (Van Diest et al., 2009). Perhaps, the existence of too many breathing centers to guide respiration 
is the most important reason for irregularity. Inspiratory reflex could come from any one of the breathing centers; a negative thought can evoke a deep sigh, etc. (Bruce \& Daubenspeck, 1995 as cited in Roth, 2005). The faulty breathing pattern can become habitual (Mitchell 2003). Resulting increased $\mathrm{CO}_{2}$ levels evoke catecholamine production, and then an abrupt decrease of $\mathrm{pCO}_{2}$ causes hyperarousal. The quick alteration of carbon dioxide level could be followed by compensatory electrolyte transport and buffering mechanisms, but only with significant time lag which may be as long as a week. On the other hand frequently elevated carbon dioxide levels increase catecholamine output, which are not neutralized by compensatory decrease of pCO2 levels, so they enhance each other's effect. (See above). Other hormones (e.g. cortisol) also can play a role (Bailey et al., 2003; Gorman, 2003). The interaction between cortisol and noradrenaline is controversial - cortisol seems to attenuate noradrenaline induced panic symptoms (Vasa et al., 2009). Progesterone influences arousal level probably via altering carbon dioxide level, it is thought to be responsible mainly for the high female/male ratio of anxiety disorder (Saaresranta \& Polo, 2002). All dynamic cells within the human organism (neurons, smooth-, skeletal- and cardiac muscle cells, pacemaker cells of heart) become activated parallel with arousal. This can result in somatic sensations and fear. Both reasonable and unreasonable fear can create vicious circles throughout the brain circuit. Misinterpretation of bodily sensations caused by hypocapnia and irregular breathing maintain and accelerate these vicious cycles; Pavlovian reflexes may develop. The alternating carbon dioxide, catecholamine, and emotional tension levels can interfere with each other, in this way the arousal can be sustained, which can maintain psychological uncertainty and provoke a vicious circle.

\section{Is there a connection between tendency to hypocapnia and neuroticism?}

Hypocapnia is typically associated with anxiety states (Grossman, 1983). On the other hand there is a great overlap between the hyperventilation syndrome and anxiety disorder, and especially panic disorder (Cowly \& Roy-Byrne, 1987; Gardner, 1996; Han et al., 1997). There is also growing amount of evidence that there is an inverse correlation between $\mathrm{pCO}_{2}$ and both of personality trait neuroticism and psychiatric morbidity (Stegen et al., 1998; 1999; 2000; 2001 as cited in Van Diest et al., 2003). A negative relationship of $\mathrm{FetCO}_{2}$ (resting endtidal fractional concentration of $\mathrm{CO}_{2}$ ) was found with trait negative affectivity. "The existence and direction of an association between $\mathrm{FetCO}_{2}$ and trait negative affectivity is clinically important for a number of topics in the field psychosomatic medicine."; "...an association of trait negative affectivity with $\mathrm{FetCO}_{2}$ may help to clarify the hypothesized role of hyperventilation in quite a number of pathological conditions, such as panic disorder, somatization, chronic fatigue syndrome, chronic muscle pain, and multiple chemical sensitivity." (Van Diest et al., 2003). Shu et al., (2007) proved that neuroticism is linked with self-reported symptoms of anxiety in hyperventilation syndrome. A robust significance was found probable due to the clinically homogeneous sample, (similar aged males were observed during military training). On the other hand, Dhokalia et al. (1998) found positive correlation between neuroticism and $\mathrm{FetCO}_{2}$ in nonclinical sample. Yet, other studies found no association between $\mathrm{FetCO}_{2}$ and anxiety (Wientjes \& Grossman, 1994 as cited in Van Diest et al., 2003). The effect of emotions on $\mathrm{pCO}_{2}$ and breathing patterns is also known (Masaoka \& Homma, 1999). One's sensitivity to carbon dioxide challenge may prove to be a useful test for psychosomatic investigations (Shershow et al., 1973). It was found that childhood anxiety disorders, particularly separation anxiety, are also associated with $\mathrm{CO}_{2}$ 
hypersensitivity (Pine et al., 2000). Carbon dioxide hypersensitivity was not found specific to panic disorder, rather to anxiety disorder. It is a question whether breathing abnormalities (written in Wilhelm, 2001a, 2001b, 2001c; Meuret, 2005; Roth, 2005) induce personality trait neuroticism (through hypocapnia) or is it in reverse? Are breathing abnormalities reversible or not (Meuret et al., 2005)? Is neuroticism a reversible personality trait or not? According to a population-based twin study a substantial overlap was found between the genetic factors "that influence individual variation in neuroticism and those that increase liability across the internalizing disorders, helping to explain the high rates of comorbidity among the latter." (Hettema et al, 2006). The identical twins breathe in similar ways (Shea et al., 1989 as cited in Homma \& Masaoka, 2008.) The negative affectivity, neuroticism could alter breathing pattern, because the breathing has plasticity (Mitchell \& Johnson, 2003). It means that genes have important role in "neuroticism” but these genes are not specific for a special anxiety disorder. Possibly, is there only one (general) neurotic syndrome (Andrews et al., 1990)?

We have to agree with Van Diest et al. (2003) that while "hyperventilation is a well known response to stress and anxiety, less attention has been paid to the opposite response", i.e. to the end-tidal hypercapnia. Because carbon dioxide is a very effective chemical, a minimal increase of its concentration can effectively influence the metabolism of the organism. The elevated carbon dioxide level may be one of the causes of psychosomatic disorders. It is well known that anger through high $\mathrm{FetCO}_{2}$ is a significant independent predictor of hypertension -- at least in females (Van Diest et al., 2003; Scuteri et al., 2001). An early hypothesis also predicted the importance of anger in pathomechanism of hypertension (Alexander, 1939 as cited in Scuteri et al., 2001). Anger itself influences the development of cardiovascular diseases (Eng et al., 2003). A person having type D personality is predisposed to several organic diseases, e.g. to coronary heart disease (Mols \& Denollet, 2010). According to Pedersen \& Denollet (2003) type D personality predicts increased risk for cardiovascular morbidity and mortality (odds ratios are from 4.1-8.9). High $\mathrm{FetCO}_{2}$ probably also plays part in the pathomechanism of type D personality, since anger is a feature of type D personality.

\section{Panic disorder, hyperventilation syndrome, generalized anxiety disorder, depression}

If we accept Andrews' et al. (1990) hypothesis, that there is only one "general neurotic syndrome", we have to demonstrate the main differences among the different anxiety disorder syndromes. Undeniably, there is large overlap between the symptoms of hyperventilation syndrome and panic disorder (Cowly \& Roy-Byrne, 1987; Han et al., 1997). The somatic symptoms of the two diseases are entirely the same, except for the fact that there is no panic attack in the hyperventilation syndrome. Chronic hypocapnia occurs in both disorders, also there are decreased bicarbonate levels associated with both (Gorman et al., 1985; Papp et al., 1989). The most important difference between the two conditions probably lies in the explicit irregularity of breathing in panic disorder (Wilhelm et al., 2001b; Caldirola et al., 2004); breathing irregularity is not proven to be definitely connected to hyperventilation syndrome.Regular chronic hypocapnia involves compensatory processes, partly via renal, (Gennari et al., 1972), partly via tissue buffer mechanism (Boron, 2004). Intracellular $\mathrm{pH}$ may become completely neutralized, in which case the patient has no symptoms. The intracellular $\mathrm{pH}$ can be balanced between chronic hypocapnic alkalosis and "compensatory" metabolic acidosis in the case of panic disorder (Sikter et al., 2009). Panic 
attacks usually start with a sudden increase of carbon dioxide level up to or slightly above normal levels (Klein, 1993). The sudden increase of carbon dioxide level also evokes acute, robust hypocapnia (via a brainstem reflex) - the panic attack begins definitely in this period (Gorman, 2003). What has happened? We can see it on Fig. 1.

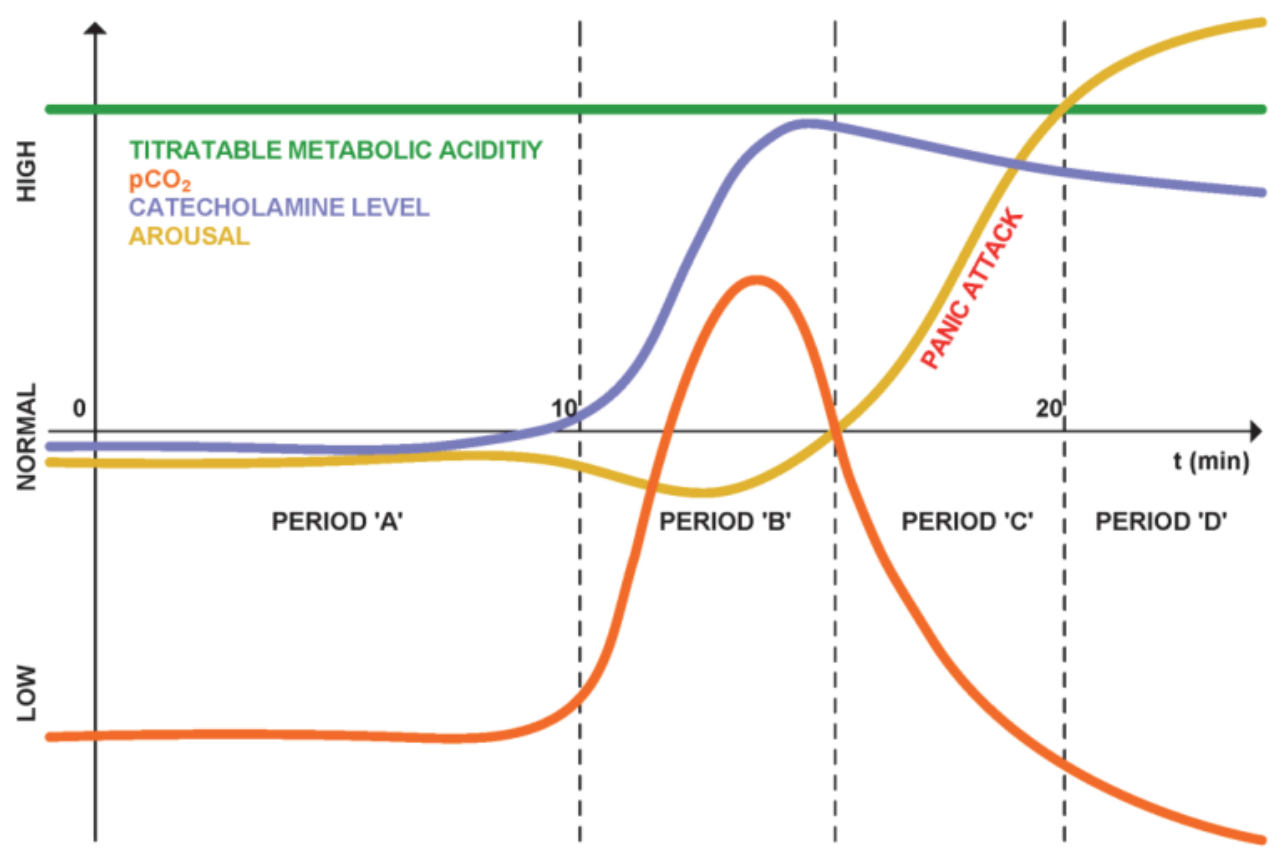

Fig. 1. Schematic diagram of respiratory panic attack, hypothesis (Sikter et al., 2009)

In period ' $\mathrm{A}$ ' chronic hypocapnic alkalosis balances chronic metabolic acidosis, the intracellular $\mathrm{pH}$ is neutral, the arousal response is normal. In period ' $\mathrm{B}$ ' the $\mathrm{CO}_{2}$ level starts to increase sharply, intracellular $\mathrm{pH}$ becomes acidotic secondary to the high penetrance of $\mathrm{CO}_{2}$, catecholamine release from different cells increases, e.g. noradrenaline output from locus coeruleus (Filosa et al., 2002) ; the cells' sensitivity to catecholamines decreases and the entire arousal response diminishes slightly. In period ' $\mathrm{C}$ ' the $\mathrm{CO}_{2}$ level decreases reflexively, intracellular $\mathrm{pH}$ becomes alkalotic, cellular/neuronal responsiveness to catecholamines increases, catecholamine level continues to be elevated, there is ongoing hyperarousal. In period ' $\mathrm{D}$ ' there is an exaggerated hyperventilation, catecholamine level decreases slowly to normal (the half life of noradrenaline is one or two minutes) (Benedict et al., 1978), although the arousal level remains high for longer because of fear and fright. In this "psychogenic period" (period ' $\mathrm{D}^{\prime}$ ) $\mathrm{pCO}_{2}$ might decrease further while catecholamine level may continue to increase (this is the "fight or fright" stress response).

The $\mathrm{CO}_{2}$ challenge test has been used for decades (Schaeffer, 1958). $\mathrm{CO}_{2}$ proved far more potent in eliciting the symptoms of anxiety/panic than did voluntary hypocapnia. This fact became a serious point of argument. Believers of the "false suffocation alarm model" (Klein, 1993) argue that hypercapnia, not hypocapnia, is the cause for the panic attack. It was overlooked that the $\mathrm{CO}_{2}$ challenge test is also biphasic---hypercapnia is followed by 
hypocapnia after cessation of exposure (Gorman, 2003). We should notice that there are similarities among the various stress responses, (e.g. the modified acute stress response) (Steen et al., 1988; Bracha, 2004), that of the panic attack (Sikter et al., 2009), and the carbon dioxide challenge test (Gorman, 2003). Gorman pointed out, that panic attack started after $\mathrm{CO}_{2}$ provocation in the hypocapnic period: "...in panic disorder patients, we have found that elevated cortisol, fear and hypocapnia are intercorrelated in the few minutes before actually experiencing an acute attack." The mechanism is biphasic in all the three types of situations; a hypercapnic period is followed by a hypocapnic one. Chronic hypocapnia is protective against panic attack, as it was stated by Klein (1993), although it is also a precondition for panic attack of the respiratory subtype. On the other hand, acute hypocapnia can evoke panic attack also (Ley, 1985), although only after abruptly elevating the carbon dioxide level. According to authors of this chapter the intra- and extracellular $\mathrm{pH}$ is successfully compensated initially, before the attack, but the acute hypercapnic acidosis would eventually be overcompensated and lead to acute hypocapnic alkalosis. The main problem is that the various compensatory mechanisms work on different time scales. Changing of the carbon dioxide level can change in the entire organism in a few seconds while the elimination of catecholamines last for several minutes, and clearing the blood from metabolic (titratable) acidity takes at least one week (Gennari et al., 1972). This is one of the many reasons why there are no perfect compensatory mechanisms.

Researchers who deny the role of hypocapnia in panic attack usually cite studies that didn't find hypocapnia using transcutaneous measurement of $\mathrm{pCO}_{2}$ (Hibbert \& Pilsbury, 1988, 1989; Garssen et al., 1996; as cited in Roth, 2005). However, it is proven that there is a 7-8 min time lag between the end-tidal and transcutaneous measurement of $\mathrm{pCO}_{2}$, the latter being delays, on the other hand its absolute level is much higher (Wollburg et al., 2009). Often, by the time this parameter is measured, the panic attack is already over. We never stated anyway that all panic attacks would be of respiratory origin.

According to the above described panic theory, the hyperventilation syndrome would differ from panic disorder in that in it the sudden, significant increase of the carbon dioxide level was absent, perhaps secondary to weaker defense mechanisms against hypocapnia in hyperventilation syndrome than in panic disorder. The second possibility may be a consequence of personality type (there is no fear or fright from somatic sensations) or it may be a learned behaviour (e.g. after psychotherapy). Is it possible that with the help of cognitive psychotherapy, and through cessation of psychogenic vicious cycles a patient with panic disorder could be "switched" to hyperventilation syndrome instead? (See Fig. 2.) During period ' $\mathrm{C}$ ' the signs of sympathicotonia appear, although it is not followed by "psychogenic" period ' $\mathrm{D}$ ' because of lack of fear. According to our panic model residual symptoms and breathing abnormalities would remain even after cognitive psychotherapy (Meuret et al., 2010), which explains why one commonly finds evidence for the exacerbation of panic disorder during long-term clinical follow ups (Durham et al., 2005).

In the resting state the $\mathrm{pCO}_{2}$ levels of GAD patients were slightly lower than that of normal controls (Wilhelm et al., 2001b). Their breathing irregularity was milder than that of patients with panic disorder, nevertheless there was disordered breathing. Oscillating $\mathrm{pCO}_{2}$ levels can evoke higher arousal even when slightly below normal (Bruton \& Holgate, 2005). Intracellular $\mathrm{pH}$ also interferes with oscillating catecholamine levels and causes fluctuation of arousal. Namely both $\mathrm{pCO}_{2}$ and catecholamine levels are fluctuating but at different rates - their effects on arousal sometimes add up, sometimes netting a weaker response. Neurons in the brain are working synchronously. Neurons that are linked together are able to become 


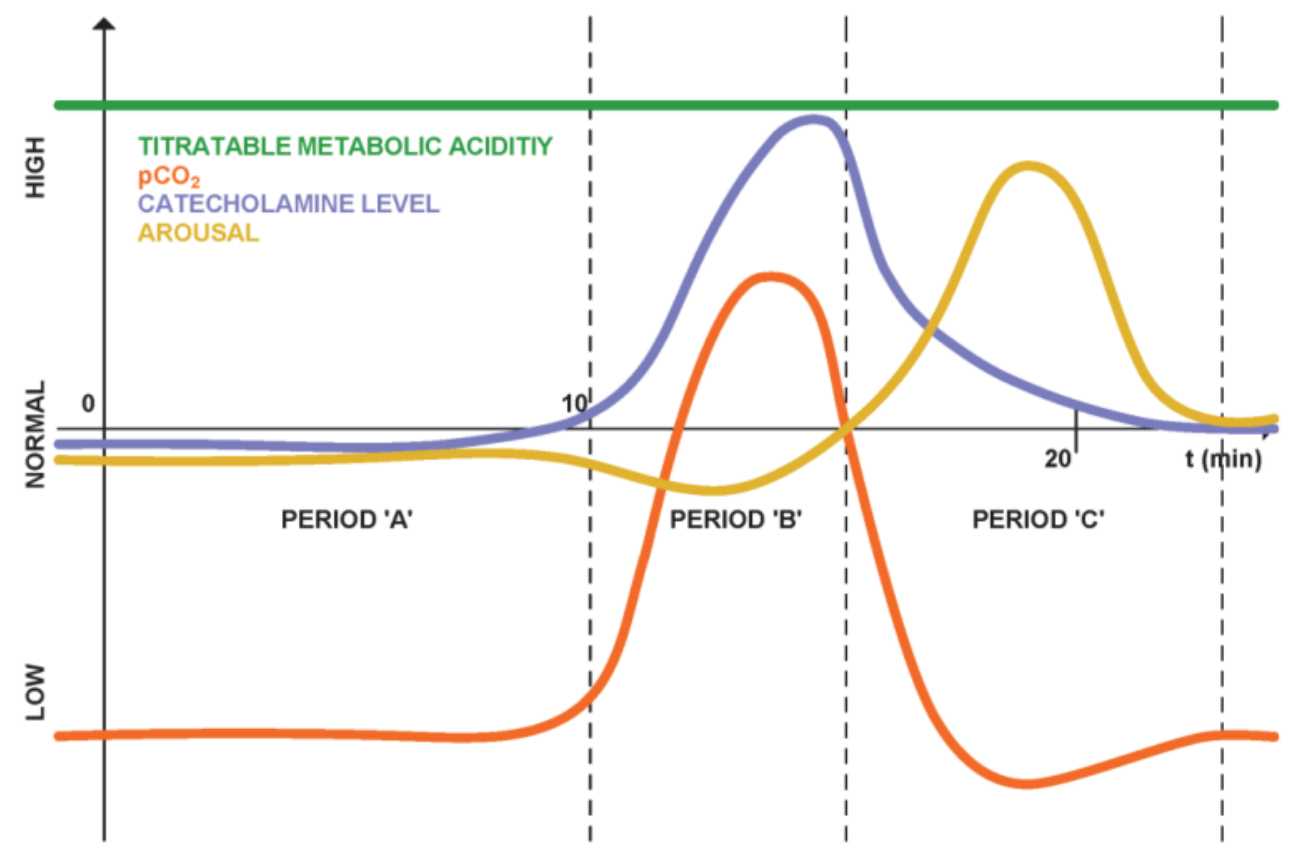

Fig. 2. Schematic diagram of respiratory panic attack after psychotherapy, (hypothesis)

both hypo- and hyperarousal. Positive and negative emotions also affect breathing patterns and arousal (Homma \& Masaoka, 2008). "In respiratory patterns, respiratory rate is changed dramatically by emotional changes. It can also be emphasized that changes of respiratory rate are related to individuality." This cavalcade of alterations can make a person psychologically unstable and can initiate vicious cycles through psychogenic mechanisms.

Clinically, anxiety is a hyperarousal, depression is a hypoarousal manifestation of an "internalization disorder" with the participation of the limbic system. This concept is supported by the presence of associated comorbidities. "An estimated $85 \%$ of adults with depression experience significant symptoms of anxiety, and $58 \%$ have a diagnosable anxiety disorder during their lifetime" (Gorman, 1996/1997; Kessler et al., 1996 as cited in Lenze et al., 2000). Anxiety disorder is linked with dysthymia as well as with major depression. Generalized anxiety disorder is associated with dysthymia much more frequently than with bipolar or unipolar depression (Pini et al., 1997). It seems as if anxiety and depression would be the two end extremes on the spectrum of the same disease entity. Generalized anxiety disorder stands in the middle. As we mentioned above, in GAD $\mathrm{pCO}_{2}$ levels oscillates around a normal baseline, and its interference with catecholamine levels and emotional tension would alternately result in anxiety or dysthymia. (See above.)

We suggest that every hyperarousal state has hypoarousal periods as well. The $\mathrm{pH}$ changes have to be corrected from time to time to maintain homeostasis. (Cytosolic $\mathrm{pH}$ is limited to a narrow range even in pathological conditions.) According to the authors' hypothesis there are three ways for the neurons of limbic system to become hypoaroused and thus result in clinical depression. A./Via cytosolic acidosis, e.g. through increasing $\mathrm{pCO}_{2}$ level. B./Existance of high basal cytosolic $\mathrm{Ca}^{2+}$ level in major depression (e.g. in neurons of 
hippocampus), which is partially genetically determined. C./Running out of ATP. (Example: intracellular alkalosis increases inward $\mathrm{Ca}^{2+}$-current, this $\mathrm{Ca}^{2+}$ overload requires more pumping activity and ATP energy -- the energy supply may become insufficient after a long-lasting alkalosis. The increased $\mathrm{Ca}^{2+}$ conductance and good energy supply at the questioned neurons are prerequisites of anxiety, while low $\mathrm{Ca}^{2+}$ conductance and ATP deficiency lead to depression.) There are very important differences between dysthymia and major depression. Dysthymia is a functional disorder, it is constantly changes in severity and alternating with anxiety. Major depression (unipolar) is extremely stable; without treatment it result in hippocampal atrophy (Sheline et al., 1996; Videbech \& Ravnkilde, 2004). This suggests that it could be an organic disorder. (See: Sick Cell Syndrome).

\section{Sick cell syndrome as a manifestation of the Second Law of Thermodynamics}

Life needs stability and high-grade permanency, which is only a surface because it is the resultant of two opposite processes, namely of anabolism and catabolism. If the two are in equilibrium, a steady state exists. The life seems to contradict the Second Law of Thermodynamics, because cell/organism exist persistantly on higher energy level than its surround. It looks as if the Second Law of Thermodynamics could not prevail in biology. It was said dogmatically in the 20th century, that is because the "life (cell/organism) is an open system". Though it has proven for the last two decades, that the living cell/organism is not totally and not always open for its surround (Hayflick, 2007), the Second Law of Thermodynamics can prevail tendentiously also in biology. It cannot be otherwise, because plenty of incidents would not be explicable. How might be, that nearly all well known illness is linked to magnesium deficiency and calcium accumulation in the cells? How might be, that our force gradually decreases after 25 year-old, and it does not increase by chance for a longer period? How might be, that everybody dies? Etc. The amount of adenosine triphosphate (ATP) is the best index of viability, because cells use this "biological energy" almost exclusively during energy required biochemical procedures. A cell usually dies, if it looses two-thirds of its ATP content (Farber, 1973). Specific ion transport ATP-ases $\left(\mathrm{Na}^{+}, \mathrm{K}^{+}-\right.$ ATPase, $\mathrm{Ca}^{2+}$-ATPase, $\mathrm{H}+-$ ATPase, etc.) "pump" specific ions across cell membranes. It costs a lot of energy (30-45\% of basal metabolic rate). Antiporters (e.g. sodium-calcium exchanger) and symporters (e.g. co-transpors) use electrochemical potential difference of ions (in this way using ATP energy indirectly). Every cell has different primary and secondary transporters, which exert to maintain and restore the interior ionmilieu. (According to Claude Bernard, the constant "milieu interieur" would be the guarantee of viability and eternal life.) ATP content of cells decreases with aging and illnesses (Barbagallo et al., 1999). Cells/neurons struggle against equilibration of ions in their whole life, to maintain chemical potential of ions between extra- and intracytosolic space. The authors created a hypothetical equation based on literature data:

$$
\frac{[\mathrm{K}+] \times\left[\mathrm{Mg}^{2+}\right] \times\left[\mathrm{HPO}_{4}^{2-+} \mathrm{H}_{2} \mathrm{PO}_{4}^{-}\right] \times\left[\mathrm{Zn}^{2+}\right] \times[\mathrm{N}]}{\left[\mathrm{Ca}^{2+}\right] \times\left[\mathrm{Na}^{+}\right] \times\left[\mathrm{Cl}^{-}\right] \times\left[\mathrm{H}^{+}\right]}
$$

According to the Equation 1. the ATP concentration of cell correlates with concentrations of $\mathrm{K}^{+}, \mathrm{Mg}^{2+}, \mathrm{Zn}^{2+}$ and inorganic phosphate $\left(\mathrm{P}_{\mathrm{i}}\right)$ (we also name them "cytosolic ions"), and ATP 
inversely correlates with the cytosolic concentrations of $\mathrm{Ca}^{2+}, \mathrm{Na}^{+}, \mathrm{Cl}^{-}$, and $\mathrm{H}^{+}$(we also name them "extracytosolic ions"). Resting membrane potential also correlates with ATP concentration and the quotient of the fraction (Bilbrey et al., 1973). (It was practically speaking earlier, that resting membrane potential is equal with "potassium potential".) It is indirectly proved, that nitrogen (=protein $\mathrm{N}$ ) content of sick cells also decreases parallel with ATP and electrolytes in the numerator after their long-lasting existence (Wacker \& Williams, 1968; Wang et al., 2004). Lack of intracellular $\mathrm{K}^{+}$correlates with $\mathrm{Mg}^{2+}$ (Whang et al., 1992), there is also connection between lack of $\mathrm{Mg}^{2+}$ and inorganic phosphate (Quamme, 1997). Elevated basal cytosolic $\mathrm{Ca}^{2+}$, decreased $\mathrm{Mg}^{2+}$ and ATP are the missing links, which may join several endemic, aging-associated disorders together (Barbagallo et al., 1997, 2009). Intracellular $\mathrm{Zn}^{2+}$ content correlates with protein content (Walsh et al., 1994). Relations of $\mathrm{K}^{+}$, $\mathrm{Mg}^{2+}, \mathrm{Zn}^{2+}$, inorganic phosphate, and protein of the sick cells are constant, and correlate with ATP content - in the case of steady state. It is hypothetically a universal biological thesis, the consequence of the Second Law of Thermodynamics. We could differentiate the functional disorders (e.g. anxiety disorder) from the organic ones (e.g. delirium in elderly people, organic psychosyndrome), that "sick neurons" of previous patients' brain would contain normal, but of latter would contain decreased amount of protein.

\section{The role of ions in anxiety disorder}

There is substantial amount of data about magnesium deficiency, excitability of neurons, stress and similar topics (Durlach et al., 1997). The relationship between magnesium deficiency and aging is obvious (Barbagallo et al., 2009). There is also huge amount of data supporting the importance of electrolyte function to the body and the consequences when imbalance occurs. It seems that the electrolyte disturbance belongs to the "disease" itself. To avoid chaos we had to model diseases, the result is the Modified Sick Cell Syndrome. (See above.) Its essence is the followings: The lack of "cytosolic ions" $\left(\mathrm{K}^{+}, \mathrm{Mg}^{2+}, \mathrm{Zn}^{2+}\right.$ and $\left.\mathrm{HPO}_{4}^{2-} / \mathrm{H}_{2} \mathrm{PO}_{4}^{-}\right)$develops always together in sick cells in the case of a steady state. Its lack is inseparable from accumulation of "extracytosolic ions" $\left(\mathrm{Na}^{+}, \mathrm{Ca}^{2+}, \mathrm{H}^{+}\right.$, and $\mathrm{Cl}$ ) in cytosol. The alterations are proportional with decrease of ATP, namely $\mathrm{Mg}^{2+}$ : ATP (and also other "cytosolic ions") ratios remain stable in steady state. Resting membrane potential usually decreases also proportionally. (Although these statements are simplifications, reality is surely complex. This model is only a compass.) Usually more ions enter cytosol than leave it. Volume of damaged cells increases at first because of increased osmolality. Protein content of cytosol also starts to degrade - proportionally to ATP and "cytosolic ions" -after a long-lasting disease (see Equation 1.) the cell starts to atrophy. Electrolyte deficiency was rarely investigated parallel intracellularly, authors usually analyse them one at a time. Symptoms caused by potassium deficiency (adynamia, fatigue, tiredness, muscular weakness, emotional and mood instability, apathy, nausea, feeling of metallic taste, tinnitus, hearing problems, meteorism, constipation, orthostatic hypotension, non-characteristic cardiac symptoms; in more severe cases vomiting, areflexia, paraesthesia, tetaniform symptoms, etc.) can be very easily misinterpreted as "neurotic symptoms”. Symptoms of experimental, human phosphate deficiency (including weakness, loss of appetite, bone pains, malaise) can also appear like anxiety (Lotz et al., 1968). The main symptoms of zinc deficiency include anorexia and weight loss, which are at the same time frequently occurring functional symptoms (e. g. in anorexia nervosa). The pathological role of zinc deficiency is also well known (Sandstead et al., 2000). Neurons are very sensitive to 
magnesium deficiency and even a small deficiency may cause hyperirritability. It is known that anxiety and stress are related to magnesium deficiency (Galland, 1991-1992; Grases et al., 2006). Magnesium (and consequent cytosolic electrolyte)-deficiency is not specific to a certain functional disease (Durlach et al., 1997). Elevation of intracellular proton concentration is a part of Sick Cell Syndrome. However, not only intracellular acidosis, but potassium and/or magnesium and/or phosphate deficiencies can cause hyperventilation, also (Knochel, 1977). At the same time, long-term hypocapnia reduces the concentration of ionized magnesium and causes hypokalemia and hypophosphatemia (Watt et al., 2001). This is also supported by study of Paleologos et al. (2000). Therefore, the possibility of development of a vicious circle is given. Lactate-induced panic reaction was more intensive in those panic disorder patients, where lower serum phosphate levels were measured before administration of lactate (Gorman, 1989). Hypophosphatemia is especially important factor of the Sick Cell Syndrome, because it can generate directly ATP deficiency (Knochel, 1977) in cells according to the Path of Least Resistance (see below).

The effect of long-term of hypocapnia on ions (Okel \& Hurst, 1961; Paleologos et al., 2000.; Watt et al., 2001) is especially important since it can help to demonstrate how the Sick Cell Syndrome and the Locus Minoris Resistentiae work. It seems that apart from the abrupt effect of biphasic hyperventilation (see Fig. 1.) there is a second, slightly slower effect of chronic hypocapnia. We have to suppose that chronic hypocapnic alkalosis (after one or two hours) starts to rearrange of "cytosolic ions" in several tissues at least. There is no dramatic alteration in the extracellular space except of hypophosphatemia. On the other hand, "something" would have happened in cells (only after a long-term existance), if hypocapnia was held at a stationary level. This "something" is essentially different in each person. Hypothetesis: ATP deficiency develops in the cells/organs, which are tolerating hypocapnia less, than the others (see: Locus Minoris Resitentiae). Damage will develop in these cells according to the Sick Cell Syndrome with alterations of ions and decreased resting membrane potential of these cells. In the case of existing intracellular alkalosis (e.g. acute hypocapnia) these neurons will be "firing". Distinct people have different Locus Minoris Resistentiae, that is why the symptoms will differ (Okel \& Hurst, 1961). In the case of the alteration is moderate and/or not permanent ("functional disorders") there is no significant protein degradation, but in the case of permanent, significant noxious agent (e.g. major depression without treatment) protein degradation and atrophy also develops (Sheline et al., 1996). It seems that "functional” vs. „organic disorder" is only a quantitative question. (See: Treated vs. untreated major depression.) Intracellular $\mathrm{Mg}^{2+}$ and bioenergetic deficiency of brain neurons are proved in vivo in major depression (Iosifescu et al., 2008).

The effectiveness of electrolyte (magnesium) supplementation gives the best evidence regarding etiologic role of deficiency in the observed symptoms, since it is very hard to prove technically the intracellular ion deficiency (Durlach et al., 1997). Magnesium supplementation studies of functional diseases bring mostly positive results in depression (Cardoso et al., 2009) and in anxiety symptoms (Lichodziejewska et al., 1997). Abundant potassium intake has a protective role in brain, at least against vascular events (He \& MacGregor, 2001). It was found antidepressant effect in animal models and was suggested a potential antidepressant activity of zinc in humans (Koroczka et al., 2001).

Dr. Sikter (as practitioner internist and cardiologist) and his 13 colleagues have treated more than 1000 patients with anxiety disorder during last twenty years with mixture of salts, which contained "cytosolic ions" $\left(\mathrm{K}^{+}, \mathrm{Mg}^{2+}, \mathrm{Zn}^{2+}\right.$, and $\left.\mathrm{HPO}_{4}{ }^{2-} / \mathrm{H}_{2} \mathrm{PO}_{4}{ }^{-}\right)$together (see: Disclosure.) The patients typically had cardiac complains (palpitation, breathlessness, 
paraesthesia, fatigue and also sighing tendency, which presume hyperventilation). The female/mail ratios were 4/1-5/1. The cardiologists surprisingly experienced that complains disappeared or substantially decreased at more than $80 \%$ of the cases after several days (<7days) administering 30-40\% of the Recommended Dietary Allowance salt combination. Naturally we have to suppose placebo effect, because there was no placebo control, although the twenty-year experience is too long time to lapse. Both the doses of salts and the time of its action are very surprising, almost unbelievable. It is impossible that these amounts of salts would supplement the supposed lack of ions for several days. It was supposed that the four ions help each other in synergism, the salt mixture should have acted on breathing centre(s) to decelerate breathing. The increasing $\mathrm{pCO}_{2}$ level could decrease arousal and complains via increasing intracellular $\mathrm{H}^{+}$concentration. It is also possible, that hypophosphatemia has bigger importance, than it was thought previously (Gorman, 1989), when phosphate therapy was not tried yet. A placebo controlled study should be done.

\section{Locus Minoris Resistentiae}

Most of the diseases affect the whole organism to one degree or another. Stress, hypocapnia, electrolyte disturbances also act on the organism. Though, most of the patients have predisposed organ vulnerability to illness (or the illness worsens) from the different noxious substances. Why does a pathogen substance (in our example hypocapnia) cause different complaints? Why do different pathogen substances cause (or worsen) illnesses on the same organ in a given patient? It may be explained with the theory of the Locus Minoris Resistentiae or the Path of Least Resistance. According to the Sick Cell Syndrome theory the illness harms the metabolism of cells, degrades also its energetical basis and interior ionmilieu. In the case of any seriously harmful noxa, which affects on the organism (e.g. hyperacute illness, cancer), it causes catabolism and degrades a part of (cells)-cytoplasm. Anabolic reparation of tissues/cells cannot start until the harmful effect exists. If it stops, cells start to repair themselves, they start to rebuild cytoplasm. Cells build-in ions first into cytoplasm with ATP energy (Jeejeebhoy, 1994). The available electrolytes in the extracellular space usually are not enough to supply "hungry" repairing cells - cells of organism struggle against each other for electrolytes. Those cells having worse metabolism and less ATP content will loose fight, and they remain or become more and more ill. The cells regarded as the Path of Least Resistance are the weakest chain links of the organism. In the case of a weak harmful noxa affects on tissues/cells of the organism (e.g. alkalosis induced by hypocapnia), cells are able to repair themselves continously and fight against the damage. They restore their original ionmilieu, but not completely and not equally in the whole organism. The weakest cells/tissues get the worst of them, and they become ill, at first functionally, then organically. Cells may tolerate damage differently even in the same organ or same tissue by having different kinds of metabolism and different ATP energy contents. That statement is particularly important at organs containing electrically excitable cells (e.g. central nervous system or heart). That means certain cells will become functionally affected (and they start firing frequently or slowly) while other cells will not. That is why a noxious agent (like acute or chronic hypocapnia) can cause different mental, organic or psychosomatic disorders on different patients.

\subsection{Psychogenic asthma bronchiale as an example of Locus Minoris Resistentiae}

Organic diseases (e.g. organic pulmonary disorders as asthma bronchiale) often cause hyperarousal mental disorders too (Dratcu, 2000). On the other hand, hyperarousal mental 
disorders often provoke (or activate) asthma bronchiale attack, which is thought to be sometimes purely psychogenic (Iamandescu \& Mihăilescu, 2008). Growing amount of data proves, that hypocapnia causes bronchial spasm and maybe evokes (triggers) asthma bronchiale in patients whose Locus Minoris Resistentiae is their airway smooth muscle cells (Bruton et al., 2005). We agree with Lindeman et al. (1998 as cited in Bruton \& Holgate, 2005), "that hypocapnia has a direct effect on airway smooth muscle cells, possibly via the effect of intracellular alkalosis on intracellular free calcium concentration". Responsiveness of airway smooth muscle cells to hypocapnia is extremely different at distinct patients. Hypocapnia (psychogenic stress) can evoke asthma attack in certain patients. The provoked attack may cause also arterial hypoxia and dyspnoea, which increases the hyperventilation, a vicious cycle. We agree with Bruton \& Holgate (2005), that the generally accepted "normal" arterial pressure of carbon dioxide $\left(\mathrm{PaCO}_{2}\right)$, namely $35-45 \mathrm{mmHg}$ is too wide. The normal $\mathrm{PaCO}_{2}$ is $39-41 \mathrm{mmHg}$ according to Bruton \& Holgate (2005). There are data, which prove that $35-38 \mathrm{mmHg} \mathrm{PaCO}_{2}$ may be already in pathological range (Bruton \& Holgate, 2005). $\mathrm{pCO}_{2}$ level changes permanently during the life (we cannot "pin” it), it is not a well reproduceable parameter, the carbon dioxide sensitivity test (Schaeffer, 1958) seems to be a better one.

\section{Delirium}

It is hard to recognize what the different types of delirium have in common. Delirium is a hyperacute energy (ATP) insufficiency in central nervous system, mainly in cortex. In its background, there are different metabolic and/or organic causes.

Significant hypophosphatemia can cause sudden ATP deficiency in brain (because of the lack of inorganic phosphate in cytosol).

$$
\mathrm{ADP}+\mathrm{P}_{\mathrm{i}}=\mathrm{ATP}+\mathrm{H}_{2} \mathrm{O}
$$

According to Equation 2, cytosolic ATP concentration correlates with cytosolic inorganic phosphate concentration - in steady state. It is very difficult or impossible to differentiate between symptoms of delirium and those symptoms caused by severe hypophosphatemia on central nervous system (Knochel, 1977). If the extracellular phosphate concentration is low, the handicapped brain neurons are defeated by other cells/organs. (See Locus Minoris Resistentiae.) According to Equation 1 the membrane potential will also decrease, it gets near to the threshold potential, and will be "firing". The direct cause is often the exaggerated hypocapnia, which decreases serum inorganic phosphate level, cerebral circulation and increases $\mathrm{Ca}^{2+}$ conductance of neurons at the same time.

Delirium is observed to develop during incorrect refeeding after long-lasting starvation. (It is so called "refeeding syndrome".) Giving less minerals and more protein to the malnourished, chronically starving patients, severe electrolyte deficiency can develop in the extracellular space as well. In this case the hypophosphatemia is especially dangerous. Acute energy deficiency of central nervous system can appear among symptoms of delirium. (But patients did not drink alcohol at all.)

Delirium in "refeeding syndrome" is the key to other types of delirium. After chronic alcohol abuse delirium tremens frequently develops after alcohol withdrawal. Alcohol continuously poisons cells of the organism in the case of chronic alcoholism, but it maintains a pathological balance. After abrupt withdrawal of alcohol the balance falls over. The cells of organism start to regenerate, but the "cytoplasm building minerals" are missing, because 
they left the organism during catabolic, poisoned state through kidneys. The developing serious hypophosphatemia can cause acute energy deficiency mainly in central nervous system. Acute hypocapnia, which is an obligatory symptom of delirium tremens, decreases cerebral circulation and $\mathrm{O}_{2}$ supply, and it also increases energy demand and causes high arousal. It is not well known the connection between hypophosphatemia and delirium tremens, (that is because serum inorganic phosphate test is not a routine examination). However, incidence of hypophosphatemia is 30-50\% among hospitalized alcoholics (Funabiki et al., 1998). Hypocapnia is the most common cause of hypophosphatemia in hospitalized patients (Ratkovic-Gusic et al., 2004). There is inverse correlation between $\mathrm{pCO}_{2}$ level and hyperarousal symptoms of brain during alcohol withdrawal (Victor, 1977). Chronic alcohol intoxication is one of the best documented manifestations of the Sick Cell Syndrome.

The structure and pathology of anxiety dramatically alter with aging. This may be because (according to the Second Law of Thermodynamics) cytosol has a tendency to increase $\mathrm{H}^{+}$ and $\mathrm{Ca}^{2+}$ level with aging. Both of them decrease the $\mathrm{Ca}^{2+}$ conductance and arousal. On the other hand resting membrane potential also decreases during this process, and it gets near to threshold potential. Depolarisation of the neurons can develop suddenly at a critical value of resting membrane potential. When the $\mathrm{Ca}^{2+}$ conductance increases, arousal can arise suddenly. That is, the pathomechanism of arousal in elderly is often different from arousal in youth. Delirium often occurs among demented patients too. We suppose that the pathomechanism of delirium developing in demented patients is similar to aforesaid, although we did not find any data in relation to hypophosphatemia or hyperventilation regarding delirium in elderly. Miyamoto et al., (2001) created an animal model of "postoperative delirium in elderly". Postoperative delirium develops among those groups of elderly patients, with whom it might occur spontaneously as well. It is supposed that pathomechanism of both postoperative and elderly patients' delirium are similar. Precondition of developing delirium is pre-existing damaged brain or significant cerebrovascular insufficiency. Damaged, sick cells usually have a lower resting membrane voltage potential. The threshold potential gets closer to resting potential, that is why the damaged cells are often more excitable. Hyperventilation/hypocapnia plays an essential role also in the cases of postoperative delirium under mechanical ventilation. Patients that are mechanically hyperventilated keep on overbreathing for a while even after the operation that is why they go into delirium.

Delirium developing after hospitalization might be caused by Cannonian "fight or flight" response, because patients having damaged brain did not perceive the situation properly and they suppose to be in danger. Feeling horror they can release enormous amount of catecholamines and start hyperventilating. We suppose vicious cycle develops in the cases of spontaneously evolving delirium in elderly. Patients with damaged brain tend to get involved in hyperventilation and delirium - frequent delirium causes hypoperfusion of brain and harms it, causing more brain damage.

Because hypocapnia and lack of "cytosolic ions" play important role in the pathomechanism of delirium, both carbon dioxide and electrolyte therapy might be effective.

\section{Breathing retraining}

Based on the current literature, breathing retraining is an early curing method for anxiety disorder and asthma bronchiale, but its exact mechanism of action is not known (Courtney, 
2008). In 1952, Buteyko theorized that "hidden" hyperventilation is the basic cause of asthma (Bruton \& Holgate, 2005). Buteyko worked out a unique breathing therapy with breath control (without FetCO $\mathrm{CO}_{2}$ control). Millions used his method. It was said that it "could cure a large number of the chronic ailments affecting modern society" (Courtney, 2008). It is excluded that using Buteyko's method restores the normal carbon dioxide level, although it may be useful also in anxiety disorders. We should suppose that it stabilizes breathing and decreases carbon dioxide fluctuation (Courtney, 2008), but without controlling $\mathrm{FetCO}_{2}$ the efficiency breathing retraining is fortuitous (Meuret et al., 2008). In fact, it can be even harmful. Therapists having no equipment usually exert to make breathing of their patients steady. If they succeed to maintain breathing steady, the treatment may be partly successful. Arousal decreases, anxiety pauses, if the $\mathrm{pCO}_{2}$ level does not fluctuate. Although without equipment to monitor $\mathrm{pCO}_{2}$, this goal is often unrealistic. On the other hand, in the state of chronic hypocapnia, control mechanisms of organism can try to restore normal carbon dioxide level, which could involve irregular breathing and arousal (see panic attack). Even though it is plausible to use capnography-assisted respiratory training in the cases where chronic hypocapnia evidently exists (e.g. in panic disorder), psychiatrists start to apply this curing method only nowadays (Meuret et al., 2008; Meuret et al., 2010). Ninety-six percent of patients achieved "much" or "very much improvement" at 12-month follow-up. "...the $68 \%$ panic-free rate a12-month follow-up do suggest that this is a potentially potent therapy that warrants more definitive testing" (Meuret et al., 2008). It seems the authors were also surprised at their results, and started to underestimate them... "...We are uncertain whether the physiological correlates of anxious states that we have observed are markers, causes or simply concomitants" (Roth, 2005).

The authors of this chapter think that it is the time to end doubting about harmful force of alternating carbon dioxide levels and to undertake this issue with exquisite conviction similarly as Donald Ley and Donald Klein have done before (Ley, 1985; Klein, 1993). There is now the technology available to assess dysfunctional habitual breathing patterns in real time and in a quantifiable way. Despite this fact the thousands of therapists and trainers teach people how to breathe correctly, we found only one scientific publication on PUBMED (Meuret, et al., 2008) describing the importance of breathing regularity and its physiological implications. It would be considered common standard practice to assess the breathing pattern since its importance is well documented in orthodox medical literature. One of the authors (De Guevara) is a breathing trainer, and his experiences are the follows:

Participants are clients who are seeking alternatives to their symptoms such as anxiety, fatigue, nervousness, migraines, headaches, and unexplained chest pains. Common complaints include breathlessness, agitation, lack of attention or poor focus ability, "out of control and out of balance" feelings. The client has undergone the necessary medical tests to rule out major organic diseases.

Feedback mechanism of actual breathing patterns and $\mathrm{pCO}_{2}$ monitoring sets the stage for the client to learn how to regulate and maintain homeostatic breathing in all contexts whether relaxed or stressed, active or passive. The client's goal is to achieve pCO2 levels ranging from $38-43 \mathrm{~mm} \mathrm{Hg}$ in the end-tidal value ultimately without the use of the instrumentation. The role of the breath trainer is director at first, but later facilitator. The client learns to interpret the changes in breathing patterns, changes in carbon dioxide levels, and somatic sensations experienced in the process. Reliance on the capnograph is encouraged at first, but discouraged towards the second half of the training. 
Training focus and objective are centered on learning and self-exploration rather than prescriptive exercises based on treatment recommendations. Emphasis on normalizing pCO2 levels rather than respiratory rate. Respiratory rate, locus of breath (diaphragmatic or thoracic), are addressed in the beginning of the training, but are not the ultimate frontier. Diaphragmatic breathing does not guarantee optimal respiration. Breathing training for performance addresses and embraces negative practice or erratic breathing as part of the methodology. It is equally important for the client to be mindful of unstable versus stable breathing. pCO2 monitoring in different breathing rates while maintaining pCO2 levels in the desires range is only possible by capnography.

Restoring the breathing patterns is more of an art than a science. People learn differently and different needs require different strategies. It is about undoing patterns of unstable breathing. The body struggles to return to the old deregulated patterns. It was thought that these breathing patterns are intimately connected with memories, daily activities, emotionally charged experiences, and even leisure. The authors think that the altered pathological breathing pattern is also linked to altered interior ion-milieu of breathing centres, which helps to maintain the permanent hypocapnic state. Meanwhile the client starts to restore his/her euventilation, kidneys clear the organism from needless, noxious ions and retract the missing salts. It takes 5-7 days at least, but several weeks or months.

For the chronic over-breather where the pCO2 levels are below $37 \mathrm{~mm} \mathrm{Hg}$, reaching 40 $\mathrm{mmHg}$ gives them a sense of euphoria and relaxation. This is only experienced the first time they reached $40 \mathrm{~mm} \mathrm{Hg}$ in the initial session. After this, they seem to maintain focus, calmness and centeredness as a new inherent pattern that is unconsciously done. Other clients report feeling very fatigue when reaching $40 \mathrm{~mm} \mathrm{Hg}$ during the first session, but with sustained training, their energy levels improve dramatically and it is sustained consistently throughout the day. They experience an overall sense of well-being by improved stamina. The client who successfully completes the program reports increased focus capacity and decrease emotional reactivity in stressful events where confrontation with others is inevitable.

This is because the body is used to operating in a deregulated breathing pattern chronically. With continuous training and pCO2 monitoring, this feeling is overcame, and a more natural and easy breathing pattern with optimal pCO2 levels are achieved.

Evidently, many people could benefit from breathing training, but not all people will qualify for it. Commitment, desire to change, improve quality of life, and self-determination are traits that play a pivotal role to achieve successful outcomes. The financial commitment has been synonymous with successful outcomes in this training program. The client who successfully completes the program reports increased focus capacity, increased energy, increased relaxation, better sleep patterns, and decrease emotional reactivity in stressful events where confrontation with others is inevitable. For some clients, changing breathing patterns and increasing the $\mathrm{pCO}_{2}$ is a struggle. They report of an unnatural way of breathing when increasing $\mathrm{pCO}_{2}$ levels. We suppose that the altered intracellular ionmilieu of breathing centers is what hinders the restoration of eucapnia (see above). Only a small percentage of people do not reach successful outcomes.

In the final analysis, anxiety, whether physiological or psychological, seems to disappear when $40 \mathrm{~mm} \mathrm{Hg}$ is reached and maintained. In contrast, in other cases, by lowering $\mathrm{pCO}_{2}$ levels below $28 \mathrm{~mm} \mathrm{Hg}$. On healthy young individuals with no previous history of anxiety, anxiety symptoms were created along with other symptoms such as nervousness, irritability 
or "feeling on the edge", cold extremities, sweaty palms, tingling in the hands and palpitations.

Psychological triggers can cause anxiety state. Commonly, the current literature supports that hyperventilation is the result of anxiety state. Is it possible that anxiety can be caused by habitual unstable breathing patterns? Can behavioural hypocapnia cause a disruption in the biochemistry and phyisiology? Can said changes mediate symptoms that are difficult to explain by standard medical tests? Paradoxically, the medical literature from various specialty areas in medicine that supports the aforementioned abounds. Breathing in itself is the last sought and most underappreciated of all human activities because it is thought to be involuntary and natural. The author's (De Guevara) premise is that a person can learn to disrupt the brain stem chemoreflex by voluntary and habitual deregulated breathing patterns. Breathing is also behaviour, and like any behaviour is subject to learning, emotionally charged experiences, physical injuries, and even leisure activities like in sports or performing arts. Anxiety disappears at $40 \mathrm{~mm} \mathrm{Hg}$ in the end tidal carbon dioxide as long the participant or breathing trainee can sustain and apply the tools learned in the program. Cognitive behavioural psychotherapy is fundamental and beneficial to help people with coping strategies and self discovery of solutions to their problems. Breathing, in the context of acid-base balance, deserves more attention and recognition. This paradigm may seem to be unknown yet, but many people have experienced relief or eradication of anxiety state by learning how to self-regulate carbon dioxide levels. Participant in breathing training have learned a tool which empowers them with the knowledge and the skills to make themselves well and to take the different dynamics and stressors of life more effectively.

The authors of this chapter hypothesize that capnography-assisted breathing training helps to restore healthy interior ionmileu of cells/neurons. The curing process, the patients' capability to maintain normocapnia could be helped by administering salts containing "cytosolic ions" together, but the two methods were never tested together.

\section{Conclusion}

There is abundant amount of scientific data regarding the topic discussed in this chapter, but the freshes are not always the best data. To avoid chaos the authors made a believable dynamic model of arousal and anxiety on the cellular level. They posed very important and hard questions about related to the mechanism of anxiety and the majority of questions were answered. They brought up crucial arguments for the role of hypocapnia in anxiety disorder. Brain physiologists proved the importance of intracellular $\mathrm{pH}$ in the responsiveness and excitability of neurons. The organism tries to maintain the stability of cytosolic $\mathrm{pH}$ and ion milieu, but the various compensatory mechanisms can lead to disregulation and to different disorders as these differ from the original physiological processes. The different mechanisms have time discrepancies. (See proposed hypothetical mechanism of panic disorder.) The authors made an attempt to integrate the main theories of anxiety disorder. They pointed out, that in humans both acute stress response and panic attack are biphasic phenomena. First, hypercapnia elevates the catecholamine level; the second phase hypocapnia renders neurons hypersensitive to catecholamines. The classical carbon dioxide challenge test is designes to simulate this biphasic response: first the carbon dioxide challenge, after which the patient is moved to fresh air where he/she hyperventilates. It is well known, that patients with anxiety disorder usually have irregular 
breathing patterns and changing carbon dioxide levels (altering cytosolic $\mathrm{pH}$ ), which results in fluctuating catecholamine and cortisol levels. The parameters fluctuate in their own rhythms, and interfere with each other and also with the fluctuating psychological tension. The continually altering arousal can provoke anxiety disorder through psychogenic pathomechanism. (Increased arousal conditions and triggers differents parts of the brain, but it does not lead categorically to anxiety. See Fig. 2.)

The authors propose another model besides this "interference anxiety model". It is a fact that voluntary (or mechanical) hypocapnia provokes symptoms hours to days after the onset. Symptoms can be explained with the concept of the Modified Sick Cell Syndrome and the newly interpreted Path of Least Resistance concept that can explain how and why clinical symptoms would appear only after prolonged hypocapnia (meanwhile the $\mathrm{pCO}_{2}$ level remains on a similarly low level). Namely after a long-lasting struggle, the cells loose the "struggle for ions" according to the Path of Least Resistance and their interior ionmileu changes; they go into lower energy level with less ATP content and less "cytosolic ions", their resting membrane potential decreases, and these cells become irritable. The authors present the differences of pathomechanisms between hyperarousal in "functional anxiety disorder" and the hyperarousal observed in the delirium of various diseases and states. (They pointed out, that exaggerated hyperventilation, hypocapnia, hypophosphatemia, and ATP-deficiency of the central nervous system are the keywords in all types of delirium, which is not evident in the available literature.) The authors also define the differences between „functional” and "organic" diseases according to the Modified Sick Cell Syndrome theory, and explain that the difference is mainly quantitative.

Exertion correlates with actual arousal in the case of wild animals, because they behave instinctively, while the essence of "civilized behaviour" is to hide arousal, emotions, and instincts. Thus arousal and motion usually do not correlate in humans, which is the main cause of diseases of civilization, the authors state.

According to a new direction there is an important link between personality and hypocapnic/hypercapnic tendency of breathing, although the connection was found to be weak. $\mathrm{pCO}_{2}\left(\mathrm{FetCO}_{2}\right)$ is not a well reproducible parameter. Moreover, its "normal range" is too wide. Therefore, the authors propose systematic population surveys regarding breathing patterns, responsiveness to $\mathrm{CO}_{2}$ challenge, and to standardize personality types. It could help to understand psychosomatic disorders even better.

The authors argue that $\mathrm{CO}_{2}$ tension is one of the most important "milieu interieur" participants, and it cannot be substituted by any acid components. The ensuing "compensation" for the acidic $\mathrm{pH}$ (by metabolic components) does not mean that the homeostasis has been restored. The new steady state is similarly stable as the original was and it hinders the restoration of the original $\mathrm{pCO}_{2}$ level. Without restoring the original interior ion-milieu the organism will malfunction.

It is suggested that in patients with anxiety disorder one could achieve "restitutio ad integrum" with combination of prescribing salt supplements containing "cytosolic ions", and of psychotherapy (with the resulting cessation of psychogenic vicious cycles), and by addressing the exchange of oxygen and carbon dioxide gases through real time breathing training using capnography. All methods have advantages, but the aforementioned combined therapy would be the most appropriate approach. Psychotherapy is often causal therapy as well, but with psychotherapy alone breathing abnormalities can perpetuate, anxiety can exacerbate, unawares to the individual. The electrolyte therapy is simple, but there are no placebo-controlled trials. Although still in "child's shoes", capnography- 
assisted breathing training would be necessary to provide tangible objective monitoring and to achieve better outcomes.

\section{Acknowledgements}

This chapter is based on Sikter's et al. (2007) article. We thank Prof. Gábor Faludi and Prof. Zoltán Rihmer for the permission to apply sections of our common work. We thank Dr. Eszter Karvazy for the language improvement. We also thank Bálint Sikter fot the technical support.

\section{Nomenclature}

ATP $=$ adenosine triphosphate

DSM III = Diagnostic and Statistical Manual of Mental Disorders III is published by the

American Psychiatric Association in 1980

$\mathrm{FetCO}_{2}=$ resting end-tidal fractional concentration of carbon dioxide

$\mathrm{GAD}=$ generalized anxiety disorder

Locus Minoris Resistentiae $=$ Path of Least Resistance

milieu interieur $=$ interior milieu

$\mathrm{PaCO}_{2}=$ partial pressure of carbon dioxide in arterial blood

$\mathrm{pCO}_{2}=$ partial pressure of carbone dioxide

restitutio ad integrum $=$ restoration to original condition

vicious circle $=$ vicious cycle

\section{Disclosure}

The treatment of patients (mentioned in subchapter 7.) was carried out according to Dr. Sikter's United States Patent 5348749. (Sikter's patent has been valid since May 1992).

Dr. Sikter declares that this book chapter was not sponsored by anyone.

\section{References}

Bailey, J. E.; Argyropoulos, S. V.; Lightman, S. L. \& Nutt, D. J. (2003) Does the brain noradrenaline network mediate the effects of the $\mathrm{CO} 2$ challenge? J Psychopharmacol. 17(3):252-359.

Barbagallo, M.; Resnick, L. M.; Dominguez, L. J. \& Licata, G. (1997) Diabetes mellitus, hypertension and ageing: the ionic hypothesis of ageing and cardiovascularmetabolic diseases. Diab Metab. 23:281-294.

Barbagallo, M.; Dominguez, L. J.; Licata, G. \& Resnick, L. M. (1999) Effects of aging on serum ionized and cytosolic free calcium: relation to hypertension and diabetes. Hypertension. 34(4 Pt 2):902-906.

Barbagallo, M.; Belvedere, M. \& Dominguez, L. J. (2009) Magnesium homeostasis and aging. Magnes Res. 22(4):235-46. Review.

Bass, C. \& Gardner, W. N. (1985), Respiratory and psychiatric abnormalities in chronic symptomatic hyperventilation. Br Med J 290:1387-1390.

Benedict, C. R,; Fillenz, M. \& Stanford, C. (1978) Changes in plasma noradrenaline concentration as a measure of release rate. Br J Pharmacol. 64:305-309. 
Bilbrey, G. L.; Herbin, L.; Carter, N. W. \& Knochel, J. P. (1973) Skeletal muscle resting membrane potential in potassium deficiency. J Clin Invest. 52: 3011-3018.

Boron, W. F. (2004) Regulation of intracellular pH. Adv Physiol Educ. 28:160-179.

Bracha, H. S. (2004) Freeze, flight, fight, fright, faint: adaptationist perspectives on the acute stress response spectrum. CNS Spectr. 9(9):679-85. Review.

Bruton, A. \& Holgate, S. T. (2005) Hypocapnia and asthma. A mechanism for breathing retraning? Chest 127:1808-1811.

Caldirola, D.; Bellodi, L.; Caumo, A.; Migliarese, G. \& Perna. G. (2004) Approximate entropy of respiratory patterns in panic disorder. Am J Psychiatry. 161:79-87.

Cardoso, C. C; Lobato, K. R; Binfaré, R. W.; Ferreira, P. K.; Rosa, A. O; Santos, A. R. \& Rodrigues, A. L. (2009) Evidence for the involvement of the monoaminergic system in the antidepressant-like effect of magnesium. Prog Neuropsychopharmacol Biol Psychiatry. 33:235-242.

Courtney, R. (2008) Strengths, weaknesses, and possibilities of the Buteyko breathing method. Biofeedback 36(2): 59-63. Available from http://www.aapb.org/tl_files/AAPB/files/biof_summer_buteyko_breathing.pdf

Cowly, D. S. \& Roy-Byrne, P. P. (1987) Hyperventilation and panic disorder. Amer J Med. 83(5):929-37.

Dhokalia A.; Parsons, D. J. \& Anderson, D. E. (1998) Resting end-tidal CO2 association with age, gender, and personality. Psychosom Med 60:33-37

Dodge, F. A. \& Rahamimoff, R. (1967) Co-operative action of calcium ions in trasmitter release at the neuromuscular junction. J Physiol. 193:419-432.

Dratcu, L. (2000) Panic, hyperventilation and perpetuation of anxiety. Prog Neuropsychopharmacol Biol Psychiat. 24:1069-1089.

Durham, R. C.; Chambers, J. A.; Power, K. G.; Sharp, D. M.; Macdonald, R. R.; Major, K. A.;

Dow, M. G. \& Gumley, A. I. (2005) Long-term outcome of cognitive behaviour therapy clinical trials in central Scotland. Health Technol Assess. 9(42):1-174. Review

Durlach , J.; Bac, P.; Durlach, V.; Bara M. \& Guiet-Bara, A. (1997) Neurotic, neuromuscular and autonomic nervous form of magnesium imbalance. Magnes Res 10:169-195

Elkinton, J. R. (editorial). (1956) Hyponatremia: clinical state or biochemical sign? Circulation 14: 1027-1034.

Eng, P. M.; Fitzmaurice, G.; Kubzansky, L. D.; Rimm, E. B. \& Kawachi, I. (2003) Anger expression and risk of stroke and coronary heart disease among male health professionals. Psychosom Med. 65:100-110.

Farber, E. (1973) ATP and cell integrity. Fed Proc 32:1534-1539.

Filosa, J. A.; Dean, J. B. \& Putnam, R. W. (2002) Role of intracellular and extracellular pH in the chemosensitive response of rat locus coeruleus neurones. J Physiol. 541(Pt2):493-509.

Funabiki, Y.; Tatsukawa, H.; Ashida, K.; et al. (1998) Disturbance of consciousness associated with hypophosphatemia in a chronically alcoholic patient. Intern Med. 37:958-961.

Galland, L. (1991-1992) Magnesium, stress and neuropsychiatric disorders. Magnes Trace Elem 10:287-301.

Gardner, W. N. (1996) The pathophysiology of hyperventilation disorders. Chest 109:516534. Review 
Gennari, F. J.; Goldstein, M. B. \& Schwartz, W. B. (1972) The nature of the renal adaptation to chronic hypocapnia. J Clin Invest. 51:1722-1730.

Gorman, J. M.; Fyer, A. J.; Ross, D. C.; Cohen, B. S.; Martinez, J. M.; Liebowitz, M. R. \& Klein, D. F. (1985) Normalization of venous $\mathrm{pH}, \mathrm{pCO} 2$, and bicarbonate levels after blockade of panic attacks. Psychiatry Res. 14(1):57-65.

Gorman, J. M. (2003) Does the brain noradrenaline network mediate the effects of the CO2 challenge? J Psychopharmacol. 17:265-266.

Grases, G.; Pérez-Castelló, J.A.; Sanchis, P.; Casero, A.; Perelló, J.; Isern, B.; Rigo, E. \& Grases, F. (2006) Anxiety and stress among science students. Study of calcium and magnesium alterations. Magnes Res. 19:102-106.

Grossman, P. (1983) Respiration, stress and cardiovascular function. Psychophysiology 20:284-300.

Han, J. N.; Stegen, K.; Simkens, K. et al. (1997) Unsteadiness of breathing in patients with hyperventilation syndrome and anxiety disorders. Eur Respir J. 10:167-76.

Harvey, B. J. Thomas, S. R. \& Ehrenfeld, J. (2002) Intracellular pH controls cell membrane $\mathrm{Na}+$ and $\mathrm{K}+$ conductances and transport in frog skin epithelium. J Gen Physiol. 92:767-791.

Hayflick, L.: (2007) Bilogical aging is no longer an unsolved problem. Ann N Y Acad Sci. 1100:1-13. Review.

He, F. J. \& MacGregor, A. (2001) Fortnightly review: Beneficial effects of potassium. Br Med J. 323:497-501

Hettema, J. M.; Neale, M. C.; Myers, J. M.; Prescott, C. A. \& Kendler, K. S. (2006) A population-based twin study of the relationship between neuroticism and internalizing disorders. Am J Psychiatry. 163:857-864.

Homma, I. \& Masaoka, Y. (2008) Breathing rhythms and emotions. Exp Physiol. 93:10111021. Review.

Iamandescu, I. B. \& Mihăilescu, A. (2008) Bronchial asthma with psychogenic trigger.Rom J Intern Med. 46(2):113-8. Review.

Iosifescu, D. A.; Bolo, N. R.; Nierenberg, A. A.; Jensen, J. E.; Fava, M. \& Renshaw, P. F. (2008) Brain bioenergetics and response to triiodothyronine augmentation in major depressive disorder. Biol Psychiatry 63:1127-1134.

Jeejeebhoy, K. N. (1994) How should we monitor nutritional support: structure or function? New Horiz. 2:131-138.

Lewis, B. I. (1959) Hyperventilation syndrome: a clinical and physiological evaluation. Calif Med. 91:121-126.

Joo, Y.; Choi, K. M.; Lee, Y. H.; Kim, G.; Lee, D .H.; Roh, G. S.; Kang, S. S.; Cho, G. J.; Choi, W. S. \& Kim, H. J. (2009) Chronic immobilization stress induces anxiety- and depression-like behaviors and decreases transthyretin in the mouse cortex. Neurosci Lett. 461:121-125.

Klein, D. F. (1993) False suffocation alarms, spontaneous panics, and related conditions. An integrative hypothesis. Arch Gen Psychiatry. 50:306-317.

Knochel, J. P. (1977) The pathophysiology and clinical characteristics of severe hypophosphatemia. Arch. Int. Med. 137: 203-220.

Kroczka, B.; Branski, P.; Palucha, A.; Pilc, A. \& Nowak, G. (2001) Antidepressant-like properties of zinc in rodent forced swim test. Brain Res Bull. 55:297-300. 
Kuijpers, G. A. J.; Rosario, L. M. \& Ornberg, R. L. (1989) Role of intracellular pH in secretion from adrenal medulla chromaffin cells. J Biol Chem. 264:698-705.

Laffey, J. G. \& Kavanagh, B. P. (2002) Hypocapnia. N Engl J Med 347:43-53.

Lenze, E. J.; Mulsant, B. H.; Shear, M. K.; Schulberg, H. C.; Dew, M. A.; Begley, A. E.; Pollock, B. G. \& Reynolds C.F. 3rd. (2000) Comorbid anxiety disorders in depressed elderly patients. Am J Psychiatry. 157:722-728.

Ley, R. (1985). Blood, breath, and fears: A hyperventilation theory of panic attacks and agoraphobia. Clin Psychol Rev. 5:271-285.

Lichodziejewska, B.; Kłoś, J.; Rezler, J.; Grudzka, K., Dłuzniewska, M.; Budaj, A. \& Ceremuzyński, L. (1997) Clinical symptoms of mitral valve prolapse are related to hypomagnesemia and attenuated by magnesium supplementation. Am J Cardiol. 79:768-772.

Lotz, M.; Zisman, E. \& Bartter, F. C. (1968) Evidence for a phosphorus-depletion syndrome in man. N Engl J Med. 278: 409-415.

Lum, L. C. (Editorial). Hyperventilation and anxiety state. J R Soc Med. 1981; 74:1-4.

Masaoka, Y. \& Homma, I. (1999) Expiratory time determined by individual anxiety levels in humans. J Appl Physiol. 86:1329-1336.

Meuret, A. E.; Ritz, T.; Wilhelm, F.H. \& Roth, T. (2005) Voluntary hyperventilation in the treatment of panic disorder-functions of hyperventilation, their implications for breathing training, and recommendations for standardization. Clin Psychol Rev. 25: 285-306.

Meuret, A. E.; Wilhelm, F. H.; Ritz, T. \&Roth, W. T. (2008) Feedback of end-tidal pCO2 as a therapeutic approach for panic disorder.J Psychiatr Res. 42:560-568.

Meuret, A.E.; Rosenfield, D.; Seidel, A.; Bhaskara, L. \& Hofmann SG. (2010) Respiratory and cognitive mediators of treatment change in panic disorder: evidence for intervention specificity. J Consult Clin Psychol. 78:691-704.

Mitchell, G. S. \& Johnson, S. M. (2003) Neuroplasticity in respiratory motor control. J Appl Physiol. 94:358-374. Review

Miyamoto E, Tomimoto H, Nakao S, et al. (2001) Caudoputamen is damaged by hypocapnia during mechanical ventilation in a rat model of chronic cerebral hypoperfusion. Stroke 32:2920-2925.

Mols, F. \& Denollet, J. (2010) Type D personality in the general population: a systematic review of health status, mechanisms of disease, and work-related problems. Health Qual Life Outcomes. 8:9. Review. Available from http://www.hqlo.com/content/8/1/9

Neher, E. (1998) Vesicle pools and Ca2+ microdomains: new tools for understanding their roles in neurotransmitter release. Neuron, 20, 389-399. Review.

Okel, B. B. \& Hurst, J. W. (1961) Prolonged hyperventilation in man. Associated electrolyte changes and subjective symptoms. Arch Intern Med. 108:757-762.

Paleologos, M.; Stone, E. \& Braude, S. (2000) Persistent, progressive hypophopshataemia after voluntary hyperventilation. Clin Sci. 98:419-425.

Papp, L. A.; Martinez, J. M.; Klein, D. F.; Ross, D.; Liebowitz, M. R.; Fyer, A. J.; Hollander, E. \& Gorman, J. M. (1989) Arterial blood gas changes in panic disorder and lactateinduced panic. Psychiatry Res. 28:171-180. 
Pedersen, S. S. \& Denollet, J. (2003) Type D personality, cardiac events, and impaired quality of life: a review. Eur J Cardiovasc Prev Rehabil. 10:241-8. Review

Pine, D. S.; Klein, R. G.; Coplan, J. D.; Papp, L. A.; Hoven, C. W; Martinez, J.; Kovalenko, P.; Mandell, D. J.; Moreau, D.; Klein, D. F. \& Gorman, J. M. (2000) Differential carbon dioxide sensitivity in childhood anxiety disorders and nonill comparison group. Arch Gen Psychiatry. 57:960-967.

Pini, S.; Cassano, G. B.; Simonini, E.; Savino, M.; Russo, A. \& Montgomery, S. A. (1997)

Prevalence of anxiety disorders comorbidity in bipolar depression, unipolar depression and dysthymia. J Affect Disord. 42:145-153.

Quamme, G. A. (1997) Renal magnesium handling: New insight in understanding old problems. Kidney Int 52: 1180-1195.

Ratkovic-Gusic, I.; Kes, P. \& Basic-Kes V. (2004) Disturbances of phosphate balance: hypophosphatemia. Acta Clin Croat. 43:67-73.

Roth, W. T. (2005) Physiological markers for anxiety: panic disorder and phobias. Int J Psychophysiol. 58:190-198.

Saaresranta, T. \& Polo, O. (2002) Hormones and breathing. Chest 122:2165-2182.

Sandstead, H. H.; Frederickson, C. J. \& Penland, J. G. (2000) History of zinc as related to brain function. J. Nutr. 130: 496S-502S.

Schaeffer, K. E. (1958) Respiratory pattern and respiratory response to CO2. J Appl Physiol. 13(1):1-14.

Scuteri, A.; Parsons, D.; Chesney, M. A. \& Anderson, D. E. (2001) Anger inhibition potentiates the assocation of high end-tidal $\mathrm{CO} 2$ with blood pressure in women. Psychosom Med 63: 470-475.

Sehlmeyer C, Schöning S, Zwitserlood P, Pfleiderer B, Kircher T, Arolt V, \& Konrad C. (2009) Human fear conditioning and extinction in neuroimaging: a systematic review. PLoS One. 4(6):e5865. Review. Available from

http:/ / www.plosone.org/article/info\%3Adoi\%2F10.1371\%2Fjournal.pone.0005865

Selye, H. (1956) Stress of Life, McGraw-Hill Inc., ISBN:0070562067, New York

Sheline, Y.I.; Wang, P. W.; Gado , M. H.; Csernansky, J. G. \& Vannier, M. W. (1996) Hippocampal atrophy in recurrent majordepression. Proc Natl Acad Sci USA. 93:3908-3913.

Shershow, J. C.; King, A. \& Robinson, S. (1973) Carbon dioxide sensitivity and personality. Psychosomatic Medicine 35:155-160.

Shu, B. C.; Chang, Y. Y.; Lee, F. Y.; Tzeng, D. S.; Lin, H. Y. \& Lung, F. W. (2007) Parental attachment, premorbid personality, and mental health in young males with hyperventilation syndrome. Psychiatry Res 153:163-170.

Sikter, A.; Faludi, G. \& Rihmer, Z. (2009) The role of carbon dioxide (and intracellular pH) in the pathomechanism of several mental disorders. Are the diseases of civilization caused by learnt behaviour, not the stress itself? Neuropsychopharmacol Hung. 11:161-173. Review.

Smith, G. A., Brett, C. L. \& Church J. (1998) Effects of noradrenaline on intracellular pH in acutely dissociated adult rat hippocampal CA1 neurones. J Physiol. 12(Pt 2):487505.

Steen, J. B.; Gabrielsen, G. W. \& Kanwisher, J. W. (1988) Physiological aspects of freezing behaviour in willow ptarmigan hens. Acta Physiol Scand. 134:299-304. 
Stenkamp, K.; Palva, J. M.; Uusisaari, M.; Schuchmann, S.; Schmitz, D.; Heinemann, U. \& Kaila, K. (2001) Enhanced temporal stability of cholinergic hippocampal gamma oscillation following respiratory alkalosis in vitro. J Neurophysiol 85: 2063-2069.

Tenney, S. M. (1960) The effect of carbon dioxide on neurohumoral and endocrine mechanisms. Anesthesiology. 21:674-685.

Tombaugh, G. C. \& Somjen, G. G. (1997) Differencial sensitivity to intracellular pH among high- and low-threshold Ca2+ currents in isolated rat CA1 neurons. J. Neurophysiol. 77:639-653.

Tombaugh, G. C. (1998) Intracellular $\mathrm{pH}$ buffering shapes activity-dependent Ca2+ dynamics in dendrites of CA1 interneurons. J Neurophysiol. 80:1702-1712.

Van Diest, I.; Vuerstaek, S.; Corne, I.; De Peuter, S.; Devriese, S; Van de Woestijne K. P. \&

Van den Bergh, O. (2003) Resting end-tidal CO2 and negative affectivity. Psychosom Med 65:976-983.

Van Diest, I.; Bradley, M. M.; Guerra, P.; Van den Bergh, O. \& Lang, P. J. (2009) Fearconditioned respiration and its association to cardiac reactivity. Biol Psychol. 80:212-217.

Vasa, R. A.; Pine, D. S.; Masten, C. L.; Vythilingam, M.; Collin, C.; Charney, D. S.;

Neumeister, A.; Mogg, K.; Bradley, B. P.; Bruck, M. \& Monk, C. S. (2009) Effects of yohimbine and hydrocortisone on panic symptoms, autonomic responses, and attention to threat in healthy adults. Psychopharmacology (Berl). 204:445-455.

Victor, H. (1973) The role of hypomagnesemia and respiratory alkalosis in the genesis of alcohol-withdrawal syndroms. Ann N Y Acad Sci. 215: 235-248.

Videbech, P. \& Ravnkilde, B. (2004) Hippocampal volume and depression: a meta-analysis of MRI studies. Am J Psychiatry. 161:1957-1966.

Wacker, W. E. C. \& Williams, R. J. P. (1968) Magnesium/calcium balances and steady states of biological systems. J Theoret Biol 20:65-78.

Walsh, C. T.; Sandstead, H. H.; Prasad, A. S.; Newberne, P. M. \& Fraker, P. J. (1994) Zinc:health effects and research priorities for the 1990s. Environ Health Perspect. 102 (Suppl 2): 5-46.

Wang, Z.; Onge, M. P.; Lecumberri, B.; Pi-Sunyer, F. X.; Heshka, S.; Wang, J. Kotler, D. P.;

Gallagher, D.; Wielopolski, L.; Pierson, R. N. Jr. \& Heymsfield, S. B. (2004) Body cell mass: model development and validation at the cellular level of body composition. Am J Physiol Endocrinol Metab. 286:E123-E128.

Watt, J. W. \& Silva P. (2001) Respiratory alkalosis and associated electrolytes in long-term ventilator dependent persons with tertraplegia. Spinal Cord. 39:557-563.

Whang, R.; Whang, D. D. \& Ryan, M. P. (1992) Refractory potassium repletion. A consequence of magnesium deficiency. Arch Intern Med 152: 40-45.

Wilhelm, F. H.; Gerlach, A. L. \& Roth, W. T. (2001a). Slow recovery from voluntary hyperventilation in panic disorder. Psychosom Med 63: 638-649.

Wilhelm, F. H.; Trabert, W. \& Roth, W. T. (2001b). Physiologic instability in panic disorder and generalized anxiety disorder. Biol Psychiat, 49(7): 596-605

Wilhelm, F.H.; Trabert, W. \& Roth, W.T. (2001c). Characteristics of sighing in panic disorder. Biol Psychiat 49: 606-614. 
Wollburg, E. Roth, W. T. \& Kim, S. (2009) End-tidal versus transcutaneous measurement of PCO2 during voluntary hypo- and hyperventilation. Int J Psychophysiol. 71:103108. 


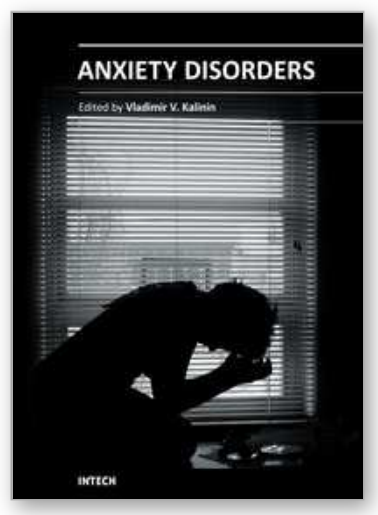

\author{
Anxiety Disorders \\ Edited by Prof. Vladimir Kalinin
}

ISBN 978-953-307-592-1

Hard cover, 324 pages

Publisher InTech

Published online 01, August, 2011

Published in print edition August, 2011

During the last 2-3 decades drastic research progress in anxiety issues has been achieved. It concerns mostly the study of different subtypes of anxiety and their treatment. Nevertheless, the data on anxiety pathogenesis is less elaborated, although here a multidimensional approach exists. It includes neurochemistry, pathophysiology, endocrinology and psychopharmacology. Again, we are able to recognize the multifarious sense of anxiety, and the present collective monograph composed of 16 separate chapters depicting the different aspects of anxiety. Moreover, a great part of book includes chapters on neurochemistry, physiology and pharmacology of anxiety. The novel data on psychopathology and clinical signs of anxiety and its relationship with other psychopathological phenomena is also presented. The current monograph may represent an interest and be of practical use not only for clinicians but for a broad range of specialists, including biochemists, physiologists, pharmacologists and specialists in veterinary.

\title{
How to reference
}

In order to correctly reference this scholarly work, feel free to copy and paste the following:

András Sikter and Roberto De Guevara (2011). A Probable Etiology and Pathomechanism of Arousal and Anxiety on Cellular Level - Is It the Key for Recovering from Exaggerated Anxiety?, Anxiety Disorders, Prof. Vladimir Kalinin (Ed.), ISBN: 978-953-307-592-1, InTech, Available from:

http://www.intechopen.com/books/anxiety-disorders/a-probable-etiology-and-pathomechanism-of-arousal-andanxiety-on-cellular-level-is-it-the-key-for-r1

\section{INTECH}

open science | open minds

\section{InTech Europe}

University Campus STeP Ri

Slavka Krautzeka 83/A

51000 Rijeka, Croatia

Phone: +385 (51) 770447

Fax: +385 (51) 686166

www.intechopen.com

\section{InTech China}

Unit 405, Office Block, Hotel Equatorial Shanghai

No.65, Yan An Road (West), Shanghai, 200040, China

中国上海市延安西路65号上海国际贵都大饭店办公楼 405 单元

Phone: +86-21-62489820

Fax: $+86-21-62489821$ 
(C) 2011 The Author(s). Licensee IntechOpen. This chapter is distributed under the terms of the Creative Commons Attribution-NonCommercialShareAlike-3.0 License, which permits use, distribution and reproduction for non-commercial purposes, provided the original is properly cited and derivative works building on this content are distributed under the same license. 